\title{
RENEWABLE ENERGY EDUCATION IN INDIA
}

\begin{abstract}
The issue of renewable energy sources that have great potential to give solutions to the longstanding energy problems of India has been considered. It has been stated that renewable energy sources are an important part of India's plan to increase energy security and provide new generation with ample job opportunities. India's plans to move towards green technology and address environmental concerns associated with the country and the world have been characterized. The peculiarities of the renewable energy education in India as a subject and as a specialized branch of engineering or science at different education levels in both governmentfunded and private institutes across India have been outlined. Science and engineering education system with detailed structure of the degree (undergraduate, postgraduate, doctoral and post-doctoral) course has been described. Comparative study of renewable energy education systems of other countries has been performed. It has been stated that currently in India science colleges offer undergraduate renewable energy course as BSc. (Renewable Energy) and Postgraduate level course (MSc) that are offered in different science institutes in the specialization of Renewable Energy, Energy Management, Energy Studies, Physics (Energy) etc. Doctoral and postdoctoral research is offered by a few science institutions in India which is a more focused research (issues) in solar energy or wind energy field. The process of studying in a number of Indian institutes specializing in renewable energy has been described and compared to other world educational establishments of Spain, Mexico, and Russia. Advantages and disadvantages of renewable energy specialization education have been defined. It has been determined that there is an immediate need for the development of requisite demonstration which should be provided at appropriate levels in which both on-job as well as traditional training in these areas should be given to the expansive audience with the aid of modern andragogy techniques.
\end{abstract}

Keywords: renewable energy, alternative energy, India, solar photovoltaic, energy, wind energy, employment, technical education system, engineering education in India.

\section{INTRODUCTION}

Energy is the most important commodity which is used daily by citizens of any country and an essential base product of the industrial growth of any country across the globe (Jennings, 2009). India is the second largest country in the world in terms of population and home of a population of more than one billion people. At present, India is the second-fastest-growing economy in the world. Due to these two major reasons, the demand for energy in India is increasing day by day. Due to its large population, pollution 
level in India has also risen rapidly in the past few years. The Indian government is planning for production of renewable energy from low level (household) to high level (solar power park or wind-generation parks). Renewable energy resources are green and do not produce any harmful greenhouse gasses. Solar energy, wind energy, thermal energy, biomass energy and tidal energy are the major renewable energy resource options in India (Tripathi et al., 2016).

Due to the geographical location of India, India has a big potential to generate solar energy. India has about three hundred clear sunny days in a year, which has the potential to generate the energy of 5000 trillion kilowatt-hours. India has a long coastal line of around 7500 kilometer which is ideal for the wind energy generation (Muneer et al., 2005; Maiti et al., 2016). Nearly $70 \%$ of population of India lives in rural areas and rural area population is living with the cattle, which can become a source of generation of biomass energy. The government of India is looking forward to fulfilling the lapsed country energy needs and increases the energy security of the country from the renewable energy systems. Postgraduate course for the renewable energy is available in India in many specializations, but due to sharply rising demand of expertise engineers for renewable energy systems in India, some technical institutes and science colleges across India have started undergraduate specialized courses related to renewable energy systems or energy system. India was one of the first countries in the world to set up an independent ministry of non-conventional energy resources (renewable energy) in 1980s and now it is in a new name - Ministry of New and Renewable Energy (MNRE) (Pillai \& Banerjee, 2009).

\section{THE AIM OF THE STUDY}

The aim of the present manuscript is to give a complete overview on the renewable engineering education in India. Energy security is now becoming a fastest growing priorities of any country and for India which is the home of around 1.21 billion people (Kanhere et al., 2017), which is around $17.5 \%$ of world population, is a must question which needs to be answered in the time of frame manner. After 2000, Indian government is taking the initiatives to increase the production of energy through renewable energy sources which not only increase the employment for Indian citizens but also give the solution to the energy security of the country. The authors outline the following objectives of the present manuscript, which are as follows: 1) to give a complete review of the engineering education in India from diploma level to postdoctoral level with specific to renewable engineering. 2) to make a brief comparative study of different institutions of BRICS countries; 3 ) to give a comparative overview of the job prospective related to renewable energy in India.

\section{THEORETICAL FRAMEWORK AND RESERCH METHODS}

Theoretical framework of the present research (manuscript) consists of current data on engineering education system, specific to renewable engineering in India. Similar type of research had been carried out in the many fields of engineering education in which control engineering, industrial engineering, production engineering, mechatronics engineering and manufacturing engineering are the major fields in India, according to different authors, such as M. Ananth (2011), P. Agarwal (2007), P. Choudhury (2016), P. Jennings (2009), S. Kaul (2016), G. Mahapatro (2016), A. Mehra (2016), S. Panda (2016), S. Sahoo (2016).

While researching we have used such modeling, formalization, abstraction and concretization.

\section{RESULTS}

India has a good number of science and technical institutes and universities which provide education to the young population of India. Admission to the science institutes for 
undergraduate courses $(\mathrm{BSc})$ is generally done on the basis of $(10+2)$ marks of the candidate. Some institutes also take their own test for the admission for undergraduate degree admission (Bajpai \& Khare, 2015). Post graduate degree (MSc) admission is done on the basis of the national level test JAM or institute level test or basis of the marks obtained by the candidate in a bachelor degree. Admission to the doctoral studies is done on the basis of one departmental test (subject and aptitude) and NET (National Eligibility Test) score obtained by the candidate in the target research subject (area). Postdoctoral admission is offered by the few premium science institutes which are done on the basis of interview and candidate research problem. Few science universities campuses run dual degree course (integrated BSc-MSc) which is five-year duration (Dixit et al., 2017). Duration of undergraduate science program is three or four years, the postgraduate program is twoyears, the doctoral program is three to five years depending on the research problem and postdoctoral program is two to three years (Kaul, 2006; Khare et al., 2015).

India has a good number of technical institutes which offer undergraduate (B.E. or B.Tech.) degree in 45 major engineering disciplines. Undergraduate admission in technical institutes in India is done on the basis of Joint Entrance Test (JEE) for national level institutes (I.I.T., N.I.T. \& I.I.I.T.) (Khare et al., 2016). JEE has two stages and it is conducted by the Central Board of Secondary Education (C.B.S.E.). Some states have joined JEE (Main) system instead of conducting their own state level entrance examination. A state level entrance examination for state government funded technical institutes is conducted by the technical education department of that state (Mehra, 2016). Private institutes and deemed universities take the admission for their undergraduate program on the basis of these two entrance examination. Some private universities take their own entrance test for undergraduate admission. For admission in postgraduate engineering degree course (M.E. or M. Tech), the candidate has to write GATE (Graduate Aptitude Test in Engineering) examination, in the chosen paper, depending on his area of the undergraduate degree. Technical institute shortlists candidates on the merit of their valid GATE score. Some technical institutes take their own test and interview. After shortlisting the candidates with valid GATE score card are able to apply for a specialized course of their choice. Part-time postgraduate engineering courses are also offered by some technical institutes for working engineers. Apart from this, Master of Science (M.S.) degree is also offered by some technical institutions which are more focused on research work and this program is specially designed for the employed sponsored candidates. Doctoral degree program (Ph.D.) in India is offered by reputed technical institutions and scholarship is provided by some funding agency (D.S.T., M.H.R.D. etc) to candidates for their research work (Agarwal, 2007).

Doctoral admission is done by the respective department of the institute, which conducts the test (based on a specialization or a field chosen by the candidate) followed by an interview. Postdoctoral research degree program is offered by few premium institutions of India in which a candidate needs to solve some industry oriented research issues. Candidates having a strong background on the subject take up research as per interest. Postdoctoral admission is done through the interview, depending on the candidate research proposal. A dual degree program is also offered in a few technical institutes as the undergraduate with a postgraduate degree which is generally five years program and postgraduate degree with a doctoral degree which purely depends on the research topic and scope. Duration of an undergraduate engineering program is four years, the postgraduate program is two years for full time and three years for a part time, the doctoral program is three to six years depending on the research problem and post-doctoral program is two to three years. In spite 
of this, India has a good number of polytechnics which offer diploma course in 60 major disciplines (Khare et al., 2014).

Providing clean, green, reliable and affordable energy for any country population is one of the biggest challenges. At the same time, clean energy technology also offers new economic opportunities as well as increases the employment. It also necessary to train dedicated human resources for this growing industry to meet this challenge and tackle today's energy-related problems. Courses associated with renewable energy systems are offered as optional or open elective paper in almost every science or technical institution across India. The college dedicated to renewable energy system has been set up in Kolkata, named NB Institute for Rural Development (NBIRT) in January 2012, which is also headed by Gon Chaudhuri, the renewable energy expert. This institute offers diploma courses and diploma certificate is given by Indira Gandhi National Open University (IGNOU) and the technical education department of the government of Queensland state, Australia (Malkki et al., 2012 ; Choudhury, 2016 ; Kumar et al., 2010).

Some science institutes, which offer the course of renewable energy, have independent renewable energy department which offers the course in the Physics department of the institute. Currently in India, few Indian science colleges offer undergraduate renewable energy course as BSc. (Renewable Energy) which is conducted in an annual pattern or semester pattern. Postgraduate level course (MSc course) is two-year course and it is offered in different science institutes in the specialization of Renewable Energy, Energy Management, Energy Studies, Physics (Energy) etc. which is conducted in semester pattern. Doctoral and postdoctoral research is offered by a few science institutions in India which is a more focused research (issues) in solar energy or wind energy field. Undergraduate level course (BSc course) is three years' duration and it has six semesters having 25 to 30 theory courses with 3-5 laboratory courses with the final year major project. First four-semesters have courses in elementary physics, chemistry, and mathematics with introductory core courses of renewable energy system. Last two semesters are dedicated to renewable energy system subject(s) Solar Thermal Energy, Wind Energy, Energy Storage System, Biomass Energy Systems, Energy Efficiency in Building and ECBC, Energy Management, Energy and Environment. Apart from this, students have one or two optional papers. Students have to choose a subject which is more related to their area of the project. The student has to complete final year project, in a group of two to five, which is more specific to current energy problems. Postgraduate level course (M.Sc course) is two year duration and it has four semesters having 12 to 15 theory courses with a final semester being partially or totally dedicated to the final year project (Bajpai et al., 2016).

Students go through the courses of Applied Mathematics, Physics for Energy studies, Chemistry for Energy studies, Biochemistry for Energy studies, Energy conversion and Energy Storage, Solar Photovoltaic Wind Energy, Geothermal and Water, Bio fuels and Bio energy, Solar Thermal Hydrogen, Energy Management etc.

Renewable energy as an independent discipline for the undergraduate degree is run in a few technical institutes in India ("Energy and Environmental Engineering", "Solar and Alternate Energy", "Energy"). Since renewable energy is an interdisciplinary field, it has subjects from electrical, mechanical, electronics, automobile, mechatronics, biotechnology and chemical engineering with its own core subjects.

First year syllabus is common to other engineering streams. Material science, fluid mechanics, thermal engineering and heat and mass transfer are major theoretical topics which are offered by the mechanical engineering department. Biochemistry and 
bioengineering are major theoretical topics offered by the biotechnology department or by applied science department of the institute. Power electronics and machines, digital electronics, electrical energy systems, analog electronics, semiconductor device fabrication technology, power system engineering, electrical equipment design, and control and solid state physics are major theoretical topics which are offered by the electrical or electronics engineering department of the institute. Courses related to biofuel and fuel cell engineering are offered by the chemical or applied science department of the institute. Major core courses are energy engineering fundamentals, material science for energy applications, energy systems modeling and analysis, energy management, energy resources, economics and environment electrochemistry, energy innovation in the different stages of the syllabus in technical institutions. Departmental elective theoretical courses are direct energy conversion, solar energy for industrial process heat conversion of energy in buildings, waste to energy etc. An elective subject associated with the renewable energy is offered by almost all technical institutes to all engineering branches in India in the final year of an undergraduate course.

Postgraduate courses (M.Tech) associated with the renewable energy or energy technologies are normally offered by the electrical engineering, mechanical engineering, environment engineering or energy study center (independent unit) of the technical institute. A few institutes in India also offer MS (by research) which is three year duration. Major theoretical topics studied under the postgraduate degree course include energy audit, energy management, energy studies, waste energy conversion technology, solar structures, solar photovoltaic technology, biomass energy, wind energy, energy modeling, energy economics, energy storage system, fuel cells, fuel cell technology and tidal energy. Besides these core subjects, elective subjects are also offered which are more related to the area of a final year project of the student for final dissertation. In the last semester, the student has to defend his/her dissertation before the external viva expert from another institution in India (Bajpai et al., 2016).

Doctoral research in India related to the renewable energy technology is done in the subfield of wind energy; solar structures, SPV technology, energy efficiency system, energy services, environmental compliance, alternative energy technologies, effluent treatment, solar concentrating collecting system, biomass characterization and $\mathrm{CO}_{2}$ sequestration as major areas. At the doctoral level, a student has to do theoretical or practical problem analysis for their doctoral thesis topic. Some research projects funded by a funding agency may form a part of their research work.

No IITs or NITs offer a specialized program on renewable energy technology (RET) undergraduate engineering degree program. Only a few IITs are offering postgraduate programs related to renewable energy technology. IIT Delhi, Kanpur, Kharagpur and Bombay have an independent energy center for research. IIT Kharagpur offers the dual degree in electrical engineering with specialization in power and energy system. Four NITs have an independent department or research centre of energy studies. Fig. 1 represents and gives the overall statistics of Renewable Energy Technology or Energy Technology (PG level) in National Institutes of Technology (thirty one in number).

National Institute of Solar Energy (an old name - Solar Energy Centre), Gurgaon, Haryana; Sardar Swaran Singh National Institute of Bio-Energy (an old name - Sardar Swaran Singh National Institute of Renewable Energy), Kapurthala, Punjab and National Institute of Wind Energy (an old name - Centre for Wind Energy Technology), Chennai, Tamil Nadu are the autonomous institutions of Ministry of New and Renewable Energy which do not offer any degree programs but offer short term diploma courses. 


\section{PG Courses in NITs}

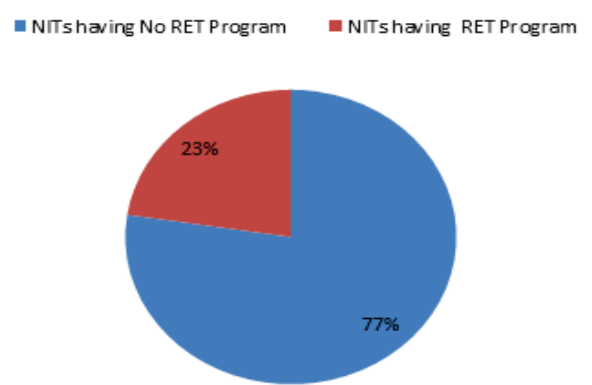

Fig. 1. Renewable Energy Technology (PG) at NITs

Indian government has taken multiple initiatives to enhance teaching and learning through the online open web medium. Indian government has developed virtual labs, open source simulation tools, textbook companion project (Scilab codes of mathematical problems), online videos lecture database through National Program for Technology Enhanced Learning (NPTEL) and online thesis management system - Shodhaganga and Shodhgangotri. Major NPTEL courses, design and optimization of energy systems, energy management systems, energy resources, energy auditing, solar energy technology, material for energy system and non-conventional energy systems are the major NPTEL courses which are available online. These courses are free to access through flash player, YouTube and download from NPTEL webserver. There is no virtual lab related to RE now and no specific tool has been developed but the mathematical modeling and mathematical calculation can be done with the help of Scilab \& Scicos. In Shodhaganga, anyone can download the doctoral thesis from the shodhaganga database and use it (Ananth, 2011; Panda, 2016).

Due to the rapid development of renewable technologies nowadays, many undergraduate students from electrical, electronics, mechanical, automobile, civil, production, industrial or mechatronics take the subject associated with the renewable technology. S. H. Saeed, C. S. Solanki, C. R. Kothari, S. Sindhuja, D. Mukherjee, R. K. Rajput, G. D. Rai, R. K. Prasad etc. are famous authors whose books are adopted as textbooks in different courses associated with renewable energy technology.

We have used widely accepted QS university ratings for shortlisting the universities of different countries to compare on renewable energy technologies.

University of Shanghai for Science and Technology, Southeast University, Wuhan University of Technology, Huazhong University of Science and Technology in China are running undergraduate and postgraduate programs related to renewable energy. These institutes have a research center in collaboration with European technical institutes (France, Spain, the United Kingdom, Greece and Italy). Moscow Power Engineering Institute is the only institute which has courses on renewable energy. Russian institutes are more focused in the area of solar cell designing, tidal energy and wind energy. Russian technical institutes have targeted programs on these fixed domains. Brazil technical institutes are not offering specialized courses on renewable technology but they integrate with electrical engineering. Centre for Renewable and Sustainable Energy Studies, Stellenbosch University, South Africa offer postgraduate degree programs in renewable and sustainable energy studies. There are many technical institutes in South Africa which offer postgraduate programs on 
energy systems. When compared to India, China, Russia and South Africa have a better laid out plan for expansion of renewable energy courses. While surprisingly Russia and China have dedicated research institutes to renewable energy. South Africa and China stand at par with India in respect to renewable energy education curriculum.

All considerable renewable energy category - solar, wind, biomass power, biofuels, small hydro, waste to energy (not completely renewable in some situations) have already made clear or will soon establish excellent growth (bio fuels conceivably belong to the latter, because presently the industry is in poor shape but is expected to gain pace in some years). A decent barometer for the sector course opportunities is the total of investments from lower than about $\$ 300$ million expenditure in 2001, investments in renewable energy inflating to about $\$ 4$ billion in 2008 , with $\$ 7$ billion in 2009-2010, investments passing over $\$ 10$ billion, at an associated annual increase rate of over $70 \%$. That's rather phenomenal. Job and career opportunities will be available in an abundance of domains within renewable energy - in manufacturing, commerce and services.

Sustainability associated products and services are $\$ 1.5$ trillion industry now and flourishing fast. Renewable energy is conceivably just around $25 \%$ of this, so you get the picture. Irrespective of further developments in manufacturing, reaching the goal of the government of $100 \mathrm{GW}$ in PV by the year 2022 could achieve 1.1 million assignments to jobs in construction, project commissioning and design, commerce improvement and operations. The report cited from the Environment and Water, Council on Energy, and National Research Development Corporation says that $30 \%$ of these employment opportunities would be highly skilled people.

The capacity for advancement in India's energy system is ample. Renewable energy presently makes up a negligible share (14.9\%) of total primary commercial energy supply while $69 \%$ of such supplies come from fossil fuels and $15.9 \%$ - from nuclear and hydro resources. The non-economic volatile biomass and wastes, which contribute to the extent of $24.5 \%$ of the total energy supplied, are shown in Fig. 2 and Fig 3.

Furthermore, if we look at the composition of renewable energy we find that $8.6 \%$ of total renewable energy is shared by wind energy while the rest $(4.5 \%)$ is distributed among solar energy $(1.3 \%)$, biomass energy $(0.5 \%)$, small hydro and power division $(1.5 \%)$ and bagasse cogen $(1.1 \%)$.
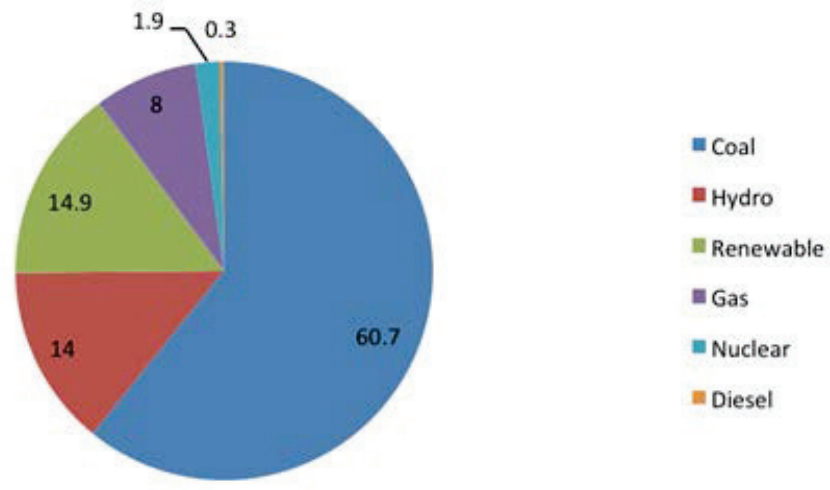

Fig. 2. Installed capacity by source in India as of 31 October 2016 (Central Electricity Authority, 2016) 
In the past decade, the furnishing of renewable energy for electricity has developed at an annual rate of $25 \%$. It has gained 30,000 MW from January 2014. During this course, wind power installation has developed about ten times and solar energy has developed from naught to 2,500 MW. At present, renewable energy accounts for about $12 \%$ of the overall electricity generation scope and contributes to about $6 \%$ of the electricity originated in the country. Renewables, accordingly, develop greater than double of the amount of electricity produced by all nuclear power stations in the country. In 2012-2013, the electricity developed by renewables was equivalent to meeting the per head annual electricity demand of about 60 million population. Greater than a million families in the country today depend entirely on solar energy for their necessary electricity needs.

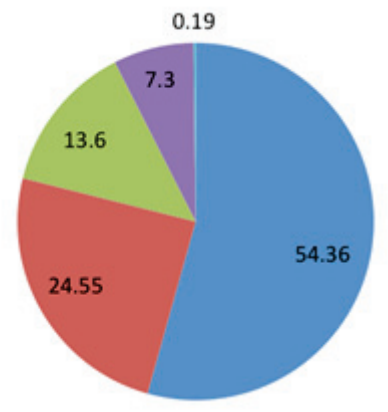

$$
\begin{aligned}
& \text { = Wind Power } \\
& \text { = Solar Power } \\
& \text { = Biomass Power } \\
& \text { = Small Hydro Power } \\
& \text { = Waste to Power }
\end{aligned}
$$

Fig. 3. Installed Grid Interactive Renewable Power Capacity in India as of September 30, 2017 as per MRNE data (Ministry of New and Renewable Energy, 2017)

India in the world ranks the fifth in renewable energy employment formulation, with 416,000 occupied in the area during 2015. In the world, about 8.1 million people are occupied in the clean energy territory. China caps the directory with 3.5 million; adhere to by Brazil with about 918,000. Corresponding to International Renewable Energy Agency's (Irena) Annual Review 2016, there was $5 \%$ more inflation than a year before in the area, with new jobs being created although employment in the broader energy sector declines. This increase is being directed by declining RE automation technology costs and sanctioning policy frameworks.

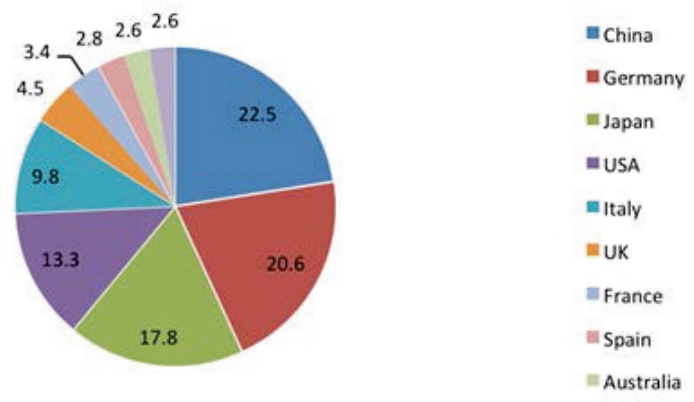

Fig. 4. Top 10 countries in 2015 based on total PV installed capacity (MW)

(Snapshot of Global Photovoltaic Markets, 2015) 

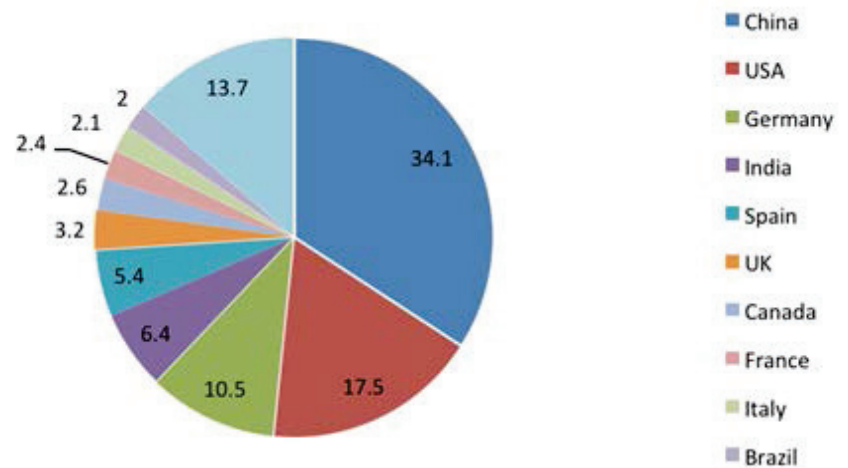

Fig. 5. Top 10 countries in 2015 based on installed capacity of wind power by country in 2015 (MW) (Global Wind Report, 2016)

As shown in Fig.4 and Fig.5 India lies the $5^{\text {th }}$ with 27,151 MW of energy production from wind energy whereas it is the $10^{\text {th }}$ in solar energy production with a total of $5,050 \mathrm{MW}$ of energy produced annually. Thanks to its position and geography, India enjoys ample potential to all of the renewable energies.

The government of India (GOI) initiates its "Make in India" program through which GOI is inviting the investors to make the manufacturing units in India. Renewable energy is one core sector which can generate the employment opportunities and at the same time, the country will also move towards to complete its energy needs. The government of India has set the target of adding $175 \mathrm{GW}$ of renewable power in the country by the year 2022. Due to the climate change issue, now automotive companies in India are pushing towards the electric vehicle technology which is zero emission technology (Sahoo, 2016; Tripathi \& Jain, 2016; Sagar et al., 2016).

\section{CONCLUSIONS}

Present scenario of renewable energy education seems to be in its beginning. With a mere number of technical institutes offering this stream in undergraduate studies leaves a void to be filled rapidly in coming years. Since the jobs are going to increase in rapid number due to the production of the energy increase, as well as the government projects and running schemes, the future of this sector is really promising. Automobile sector is now getting involved in designing the lightweight automotive which can run on solar energy. Solar energy is the area which is nearly untapped in India and can become a continuous source of energy for households.

The focus should be to ameliorate the surroundings by inexhaustible energy awareness of juvenile people concerning sustainable development and also to burgeon the inventive approach for perusing and finding possible solutions for it. It is vital for emerging and execution of a well-designed energy tutelage programs, including environmental impediment oriented to orthodox and colloquial edification in cooperation with all the organizations which are in association with energy before it is too late. A cautious scrutinization of the curriculum of numerous education programs on modern and renewable sources of energy unveils that more often the coursework is not vigorously taken by the proficient or available experts. An adequate stability between the conceptual and pragmatic inputs is critical for any sort of renewable energy pedagogy. The research labs of renewable 
energy curriculum must fortify ample hands-on experience to the students. There is an immediate need for the development of requisite demonstration which should be provided at appropriate levels in which both on-job as well as traditional training in these areas should be given to the expansive audience with the aid of modern andragogy techniques.

\section{REFERENCES}

1. Agarwal, P. (2007). Higher education in India: Growth, concerns and change agenda. Higher Education Quarterly, 61(2), 197-207.

2. Ananth, M. (2011). National programme on technology enhanced learning (NPTEL): The vision and the mission. Technology for Education (T4E), 2011, 8.

3. Bajpai, S., Asif, S., \& Akhtar, S. (2016). Electromagnetic Education in India. Comparative Professional Pedagogy, 6(2), 60-66.

4. Bajpai, S. \& Khare, S. (2015). Mechatronics Engineering Education in India. Comparative Professional Pedagogy, 5(4), 73-79.

5. Bajpai, S., Khare, S. \& Yadav, R. (2016). Control Education in India: Present \& Future. IFAC-PapersOnLine, 49(1), 813-818.

6. Ministery of Power, Goverment of India. (2016). Central Electricity Authority. Retrieved from http://www.cea.nic.in/reports/monthly/installedcapacity/2016/installed_ capacity-10.pdf", accessed September 06, 2017.

7. Choudhury, P. (2016). Growth of Engineering Education in India: Status, Issues and Challenges. Higher Education for the Future, 3(1), 93-107.

8. Dixit, U., Hazarika, M. \& Davim, J. (2017). A brief history of mechanical engineering. Springer. University.

9. Mahapatro, G. (2016). Renewable energy in India. PhD diss., Sumy State

10. Global Wind Energy Council. (2015). Global Wind Report. Retrieved from http://www.gwec.net/wp-content/uploads/vip/GWEC-Global-Wind-2015-Report_April2016_22_04.pdf.

11. Jennings, P. (2009). New directions in renewable energy education. Renewable Energy, 34(2), 435-439.

12. Kanhere, A., Pateriya, P. \& Jain, M. (2017). Acceptability and feasibility of immediate postpartum IUCD insertion in a tertiary care centre in Central India. International Journal of Reproduction, Contraception, Obstetrics and Gynecology, 4(1), 179-184.

13. Kaul, S. (2006). Higher education in India; seizing the opportunity. New Delhi.

14. Khare, S., Bajpai, S. \& Bharati, P. (2015). Production engineering education in India. Management and Production Engineering Review, 6(1), 21-25.

15. Khare, S., Chatterjee, A., Bajpai, S. \& Bharati, P. (2016). Manufacturing engineering education in India. Management and Production Engineering Review, 7(1), 40-44.

16. Khare, S., Chowdhry, S. \& Bajpai, S. (2014). Control engineering education in India. Power, Control and Embedded Systems (ICPCES), 2014 International Conference. IEEE.

17. Kumar, A., Kumar, K., Kaushik, N., Sharma, S. \& Mishra, S. (2010). Renewable energy in India: current status and future potentials. Renewable and Sustainable Energy Reviews, 14(8), 2434-2442.

18. Maiti, S., Jha, S., Garai, S., Nag, A., Bera, A., Bhattacharya, D., Kale, R. \& Deb, S. (2016). Climate change awareness among the livestock rearers of east coast of India. The Indian Journal of Animal Sciences, 86 (7). 
19. Malkki, H., Alanne, K., \& Hirsto, L. (2012). Energy engineering students on their way to expertise in sustainable energy. Scientific Journal of Riga Technical University. Environmental and Climate Technologies, 8(1), 24-28. New Dehli.

20. Mehra, A. (2016). The JEE conundrum revisited: a time for course correction.

21. Ministry of New and Renewable Energy, Goverment of India. (2017). Physical Progress (Achievements). Retrieved from http://mnre.gov.in/mission-and-vision-2/achievements.

22. Muneer, T., Asif, M., \& Munawwar, S. (2005). Sustainable production of solar electricity with particular reference to the Indian economy. Renewable and Sustainable Energy Reviews, 9(5), 444-473.

23. Panda, S. (2016). Shodhganga-a national level open access ETD repository of Indian electronic theses: current status and discussions. Library Hi Tech News, 33(1), 23-26.

24. Pillai, I., \& Banerjee, R. (2009). Renewable energy in India: Status and potential. Energy, 34(8), 970-980.

25. Sagar, A., Balakrishnan, K., Guttikunda, S., Roychowdhury, A., \& Smith, K. R. (2016). India leads the way: a health-centered strategy for air pollution. Environmental health perspectives, 124(7), 116.

26. Sahoo, S. (2016). Renewable and sustainable energy reviews solar photovoltaic energy progress in India: A review. Renewable and Sustainable Energy Reviews, 59, 927-939.

27. International Energy Agency. (2017). Snapshot of Global Photovoltaic Markets. Retrieved from http://www.iea-pvps.org/fileadmin/dam/public/report/PICS/IEAPVPS_A_Snapshot_of_Global_PV_-_1992-2015_-_Final_2_02.pdf

28. Tripathi, A., \& Jain, S. (2016). Make in India: New Mantra for Economy Growth. New Dehli.

29. Tripathi, L., Mishra, A., Dubey, A., Tripathi, C., \& Baredar, P. (2016). Renewable energy: an overview on its contribution in current energy scenario of India. Renewable and Sustainable Energy Reviews, 60, 226-233. 